DOI: 10.15290/bsp.2016.21.en.09

\author{
Katarzyna Lapińska \\ University of Białystok \\ k.aramowicz@wp.pl \\ Małgorzata Mańczuk \\ University of Białystok \\ malgorzata.manczuk@wp.pl
}

\title{
Public Participation in Polish Executive Proceedings in View of Selected European Regulations
}

\begin{abstract}
The paper presents legal possibilities of public participation in the execution of sentence. It is based on the Polish and other European countries regulations, i.e. French, English, Welsh and German examples. Above-mentioned models will be examined taking into account accessibility, effectiveness and aim of their regulations. The paper shows that entrusting third sector organizations with some responsibilities in the execution of sentence could bring measurable benefits for the convicted offenders as well as society.
\end{abstract}

Keywords: public participation, social factor, criminal proceedings, execution of sentence

\section{Introduction}

Penitentiary and post-penitentiary systems of European countries encounter numerous problems in their efforts to establish an ideal model of the execution of sentence. Their struggle to solve them generates both success and failure. All these attempts share a noticeable and systematic withdrawal from custodial sentences for the sake of non-custodial sentences while increasing a role of community in the process of the sentence execution. Participation of social factor during this stage of proceedings is to be a specific remedy for intensifying problems of prison overcrowding, prison violence and ex-convicts failing to adapt to the reality after serving their sentence $^{1}$. Council of Europe Committee of Ministers' Recommendations on the Euro-

1 B. Nowak, Reintegracja społeczna skazanych w wybranych państwach Unii Europejskiej, "Resocjalizacja Polska" 2015, No. 10 , p. 57-58. 
pean Rules on Community Sanctions and Measures $^{2}$ and on the European Prison Rules $^{3}$ draw special attention to as broad community participation, i.e. of social organizations and private individuals, as possible in the enforcement of sanctions and other measures. According to the above recommendations, social factor participating in the enforcement of sentence is to play a role of a bridge spanning convicted offenders and society and not allowing to break this bond ${ }^{4}$.

In the Polish legislation, community participation is a relatively new principle. It was introduced by the Criminal Executive Code Act in 1997. Thus executive proceedings ceased to be a sole domain of the State and its bodies. Pursuant to Art. 38 $\$ 1$ of the Act of 6 June 1997 - Criminal Executive Code (hereinafter referred to as $\mathrm{CEC})^{5}$, associations or societies, foundations, organizations and institutions as well as churches and other denominational (religious) organizations and persons of trust may cooperate in the execution or enforcement of sentence, penal measures, compensatory, protective and preventive measures, in particular connected with deprivation of liberty and forfeiture. What is more, representatives of the above entities may take part in Councils or other collective bodies appointed by Prime Minister, Minister of Justice or subordinate bodies, or Province Governors, whose task is to provide aid and support to convicts and their families or coordinate cooperation between the society and correctional institutions (prisons) and detention or custody facilities. A detailed scope, form and course of the cooperation as well as requirements to be fulfilled by the representatives of the entities are determined by Prime Minister's Regulation of 28 December 2016 on Cooperation between Entities in the Enforcement of Sentence, Penal Measures, Compensatory, Protective and Preventive Measures and Forfeiture as well as Community Control over their Execution ${ }^{6}$, which came into force on 1 January 2017. The above entities may also take part in the activities of General Council for Social Reintegration and Assistance to Convicted Offenders appointed by Prime Minister.

Representatives of these entities may also provide offenders and their families with necessary help and assistance, in particular material and medical, finding a job and accommodation and giving legal advice in order to facilitate social reintegration and, especially, counteract the return to crime. What is more, offenders are entitled to appoint a trustworthy person as their representative in a written form and upon their consent, especially from among the representatives of associations, foundations, organizations and institutions mentioned in Art. $38 \$ 1$ of the CEC. Bearing the above

2 Recommendation No. R (92)16 of the Council of Europe Committee of Ministers to Member States on the European Rules on Community Sanctions and Measures of 19 October 1992.

3 Recommendation Rec (2006)2 of the Council of Europe Committee of Ministers to Member States on the European Prison Rules of 11 January 2006.

4 A. Janus-Dębska, Praca na rzecz społeczności lokalnej w wybranych krajach europejskich, "Probacja" 2013, No. IV, p. 125-126.

5 Journal of Laws No. 90, item 557 as amended.

6 Journal of Laws, item 2305. 
in mind, a circle of entities admitted to cooperation within the execution of sentence has been outlined very broadly by the legislator. However, a given entity may participate in the process of the convict's social rehabilitation solely if its articles of association contain a clause on carrying out activity aimed at the implementation of tasks indicated in Chapter VII of the CEC. With regard to churches and religious organizations, each time these entities may only be those whose legal status has been regulated and approved of by the State ${ }^{7}$.

Social factor participation is also visible in penitentiary systems of other European countries. The French model is worth mentioning in particular, where the so called third sector plays an important role in, inter alia, drafting reports about the defendants, detaining prisoners and organizing support both to the convicted persons' families and victims themselves. Being an alternative to the operations of the State itself, this sector has been more and more often responsible for the offenders' re-adaptation and reintegration into society ${ }^{8}$. A network of institutional partners is organized while agreements between French Ministry of Justice and non-governmental organizations which provide aid and assistance to ex-inmates are concluded. These agreements are concluded both with organizations operating nationally and locally. A main purpose of this undertaking is facilitating ex-inmates' access to such goods as accommodation, work, education, health care, etc. ${ }^{9}$

An interesting fact is that statistically each French citizen is a member of at least one association and being often involved with a bigger number of non-governmental organizations. In effect, app. 14 million French citizens take an active part in the life of communities to struggle with problems contained in their articles of associations, which are usually unprofitable or forgotten by the authorities. Nevertheless, it should be pointed out that current non-governmental organizations often have nothing in common with voluntary service and unpaid help and assistance any more. This tendency is called "professionalization" of associations ${ }^{10}$. Yet, the fact that such organizations' staff receive remuneration for their work does not change the assumptions and objectives of their operation, including the context of community participation in the execution of sentence and offenders' re-adaptation and reintegration into society.

Organizations engaged in the execution of sentence by the convicted offenders are responsible, among others, for the measure called placement in the community, community work, or probation. The offenders' re-adaptation would not be possible without community participation due to the lack of such a policy by the State. The organizations provide the convicted offenders with accommodation, night refuge, food, and clothes, etc. These entities are engaged in community work, prevention

7 T. Szymanowski, (in:) T. Szymanowski, Z. Świda, Kodeks karny wykonawczy. Komentarz, Warszawa 1998 , p. 84.

8 M. Herzog-Evans, French third sector participation in probation and reentry: Complementary or competitive? "European Journal of Probation" 2014, vol. 6(1), p. 42, ejp.sagepub.com (08.11.2016).

9 B. Nowak, Reintegracja..., op. cit., p. 65.

10 M. Herzog-Evans, French..., op. cit., p. 42-43. 
and treatment of addictions, or aid and assistance provided to the victims. Other organizations operate in penitentiaries providing assistance within medical treatment, access to culture and education, or enhancing convicts' vocational qualifications. Before a sentence is rendered, non-governmental organizations prepare a pre-sentence report about the defendant. Upon the judge's request, they may also check if there are circumstances allowing probation. Ultimately, the performance of the above functions by the organizations is more economical for the State than investing in civil servants. That is why judicial bodies more and more often cooperate with non-governmental organizations. However, this trend should not be identified with this sector's privatization or private sector's domination over the public one ${ }^{11}$.

There are so many such organizations in France that we have resigned from presenting their list herein showing their share in the execution of probation focusing on the largest four instead

(Federations Citoyen et Justice, Fédération Nationale des Associations d'Accueil et de Réinsertion Sociale, Federation Addictions Federation des Associations Reflexion Action Prison et Justice) ${ }^{12}$. It might seem that such large organizations could force smaller ones out from the market, but according to the French doctrine, there is no such risk as they set up federations ${ }^{13}$. Non-governmental organizations do not eliminate state structures too even if they strive for "professionalization" of their members and actions. As pointed out, they are a complementary source of support for the convicts which is not competitive to state structures; they simply found their niche where the state itself resigned from interfering for mostly cultural reasons ${ }^{14}$.

\section{Restriction of liberty}

Restriction of liberty, particularly after changes introduced by the Act of 20 February 2015 Amending the Criminal Code Act and Some Other Acts ${ }^{15}$, is perceived as punishment alternative to suspended imprisonment. Restriction of liberty is generally imposed as an independent sanction, yet the court may exceptionally impose it together with imprisonment. Referring to the amended reading of Art. $34 \$ 1$ a of the Criminal Code, restriction of liberty may be unpaid, controlled work for social purposes, or a deduction from $10 \%$ to $25 \%$ of a monthly salary for a social goal specified by the court. Sentencing to restriction of liberty, the court imposes at least one these obligations on the convict; yet they may also be imposed together (cumulatively). What is more, adjudicating restriction of liberty, the court may impose on the convicted person obligations envisaged in Art. $72 \S 1$ points 2-7a of the Criminal Code,

Ibidem, p. 43-44

Ibidem, p. 45.

Ibidem, p. 45-46.

Ibidem, p. 46-47.

Journal of Laws, item 396. 
for instance, apologizing to the victim, undergoing addiction treatment, performing his or her obligation to maintain another person, or impose pecuniary considerations mentioned in Art. 39 point 7 of the Criminal Code for their benefit. Thus the core of this penalty is the restriction of specified spheres of the convict's freedom freedom to choose a place of residence, place of work, organize free time, or dispose of his or her salary ${ }^{16}$.

Due to the issues discussed in this article, we should mainly focus on the aspects connected with the enforcement of restriction of liberty social factor may participate in. That is why the issue of unpaid controlled work for social purposes will be discussed later. To enforce restriction of liberty, the court sends a copy of the decision (judgment) to a competent professional probation officer, who is responsible for all activities connected with the organization and control of restriction of liberty's enforcement. After hearing the convicted person, a probation officer refers him or her to a workplace designated by a competent village mayor, city mayor or city president. This work may also be performed for the benefit of institutions or organizations representing a local community, and in educational and correctional centres, youth correctional centres, youth social therapy centres, and medical treatment entities in the meaning of the provisions on medical activity, organizational units of social welfare and assistance, foundations, associations and other institutions or communal organizations providing charity services upon their consent. The choice of a proper workplace is essential for the convicted person in his or her return to society and re-adaptation. According to the relevant literature, due to a positive impact of the above form of punishment on the convict as well as its social perception, it is necessary to promptly extend the structure of entities creating workplaces and find appropriate sources of funding them. Furthermore, social organizations, foundations or entrepreneurs should be feasibly encouraged to as wide engagement in this process as possible ${ }^{17}$. A purpose of this punishment cannot be achieved without a significant extension of the facilities and structure of entities interested in cooperation with convicted offenders. Moreover, the author of this theory rejects egalitarianism in relation to the execution of unpaid controlled work for social purposes claiming that community work should be diversified to match personal attributes of the convict; situations when an economist or businessman sweeps the streets instead of helping others using their qualifications should not take place ${ }^{18}$.

Community work performed in such places as hospice or hospital in particular should eventually change the convict and make them revalue their life again ${ }^{19}$. Due to the cost of maintenance of a potential convict in prison, providing him or her with

16 R. Giętkowski (in:), R.A. Stefański (ed.), Kodeks karny, Warszawa 2015, p. 290.

17 K.A. Politowicz, O potrzebie i sposobach rozszerzania bazy dla wykonywania pracy społecznie użytecznej po nowelizacji kodeksu karnego, "Probacja" 2015, No. III, p. 94.

18 Ibidem, p. 93.

19 A. Janus-Dębska, Uwarunkowania efektywnego wykonywania kary ograniczenia wolności, "Probacja" 2014, No. III, p. 117. 
unpaid workplace is definitely cheaper. What is more, such work is not competitive to other employees or unemployed because it is most often performed for charity or unprofitable purposes, which opens immense opportunities for non-governmental organizations, local government units or religious organization $s^{20}$. Detailed principles of the execution of restriction of liberty are specified in the Regulation of Minister of Justice of 1 June 2010 on Entities Enforcing Restriction of Liberty and Community Service ${ }^{21}$. Provisions on the enforcement of restriction of liberty are also applied when, pursuant to Art. $45 \S 1$ of the CEC, the court changed a fine into community service.

Research on the functioning of cooperation between probation officers and other institutions safeguarding the performance of work by the convicts ${ }^{22}$ reveal that those sentenced to community service mostly perform it in entities designated by village mayors, city mayor or city presidents (95.2\%) and other state or local government organizational units (35.6\%). Courts cooperate with educational and correctional centres to a small extent $(29.2 \%)$, health care centres $(20.9 \%)$, charity foundations, associations and other institutions or organizations (14.6\%), institutions or organizations representing a local community (13.6\%), organizational units of social welfare (11.1\%), youth correctional centres and youth social therapy centres $(2.5 \%)$. The respondents also mentioned other entities such as: correctional facilities, botanical gardens, forest inspectorate, animal shelters, churches, and Monar centres.

The above considerations ensue a conclusion according to which restriction of liberty is a significant form of impact on convicted offenders in the Polish system. On the other hand, a German model does not envisage restriction of liberty in its catalogue of penalties. The German Criminal Code (Strafgesetzbuch) does not contain any terms or notions referring directly to restriction of liberty or community service. Nevertheless, the latter punishment is included in the Code itself and it is a measure classified as substitute penalty ${ }^{23}$. Pursuant to Art. 293 of the Introductory Act to the German Criminal Code, Land governments have been authorized to pass resolutions (they could sub-delegate powers to Lands' judicial administration) under which a fine could be replaced by community service. Generally, this rule has been in force until today. The effect of this solution is lack of uniformity in the manner of regulating this measure in the whole country ${ }^{24}$. It is also claimed that completing of penalty

20 K. Postulski, Zmiany w wykonywaniu kary ograniczenia wolności, ”Probacja" 2011, No. III, p. 121.

21 Journal of Laws No. 98, item 634.

22 A. Janus-Dębska, Współpraca kuratorów sądowych z osobami organizującymi i nadzorującymi prace skazanych w ramach kary ograniczenia wolności w świetle badań własnych, "Probacja" 2015, No. III, p. 19. At the beginning of 2014, the author of the above article carried out surveys and questionnaires in the group of judges (70 respondents), probation officers (335 respondents) and representatives of units where community service is performed (30 respondents) on sentencing and enforcement of restriction of liberty after implementation of two important amendments which came into force in 2010 and 2012.

23 A. Ornowska, "Pot zamiast odsiadki": Dylematy związane z wprowadzeniem do niemieckiego porządku prawnego elementów kary pracy społecznie użytecznej i próby ich przezwyciężenia (część I), "Probacja" 2014, No. I, p. 51. Ibidem, p. 54. 
mostly depends on the system of sentence enforcement adopted by a given Land. It has been confirmed that a penalty is much more likely to be completed if a convict has been provided with a workplace chosen by associations supporting the offender rather than court clerks or probation officers ${ }^{25}$.

The above mentioned regulation is not the only form of community service application in the German penal system. Community service elements are also contained in the institution of parole or probation when the court may impose some obligations on the defendant. A catalogue of such obligations also envisages "other community considerations" beside a duty to redress damage or pay pecuniary consideration for the State or social purpose. This expression itself encompasses community service even though it is very rarely used in practice. It is also unclear if community service adjudicated as a form of punishment can be grounded in the regulation envisaging a duty to impose injunction in a form of orders to be performed by the convict during a trial period, e.g. relating to work, education or free time. These duties may also be adjudicated in case of parole after serving a part of a custodial sentence or life sentence ${ }^{26}$.

Another institution of criminal law containing elements of community service can be found in the German Code of Criminal Procedure in the provisions on conditional discontinuation of proceedings. Pursuant to the regulations thereof, a defendant can be obliged to perform community consideration as a condition to apply the above institution ${ }^{27}$. Despite intense attempts to introduce community work modelled on the English community service model into the German Criminal Code, this idea has not been approved of by the German legislator yet. A part of the doctrine explains this deadlock by the contradiction between potential norms concerning this penalty and norms ensuing from the German constitution. Constitutional provisions straightforwardly and directly ban forced labour except penal labour and work performed as part of common and uniform public service obligations. According to the German doctrine, this catalogue does not envisage the exception for the provision of community work (service ${ }^{28}$. Moreover, we cannot forget that a ban of forced labour carries additional meaning and significance in the context of German history, which must always be taken into account by the drafters of criminal code changes ${ }^{29}$.

\section{Probation}

Probation is a main form of activity pursued by social organizations within the field of convicted offenders' re-adaptation, social rehabilitation, rehabilitation or ther-

A. Ornowska, "Pot zamiast odsiadki": Dylematy związane z wprowadzeniem do niemieckiego porządku prawnego elementów kary pracy społecznie użytecznej i próby ich przezwyciężenia (część II), "Probacja" 2014, No. II, p.141.

$26 \quad$ Ibidem, p. 55-56

$27 \quad$ Ibidem, p. 56.

28 Ibidem, p.133-134.

29 A. Janus-Dębska, Praca..., op. cit., p. 135. 
$a^{3} y^{30}$. These entities may, in particular, supervise a person whose proceedings were conditionally discontinued or who was given a parole or put on probation. Moreover, these organizations may participate in the enforcement of a fine if it has been replaced with community service (provisions on the participation of organizations in the enforcement of restriction of liberty and community service are analogical both with regard to offences and misdemeanours). What is more, social organizations may take active part in preparing ex-inmates to free life after they have been released from prison.

As part of probation, professional probation officers organize and undertake activities aimed at helping a convict socially re-adapt to counteract their return to crime as well as supervise the observance of obligations imposed on the convict by a court or those ensuing from probation (Art. 173 of the CEC). Furthermore, they manage and direct work of social probation officers and trustworthy persons enforcing probation. Detailed duties and rights of persons enforcing probation have been specified in the Regulation of Minister of Justice of 13 June 2016 on a Manner and Course of Activities Carried out by Probation Officers in Criminal Enforcement Cases ${ }^{31}$. This regulation also of provides a professional probation officer with a possibility of handing over probation to a social probation officer if he or she is authorized to waive personal probation.

What is more, a professional probation officer may entrust representatives of associations, organizations and institutions with the enforcement of probation within the scope stipulated by Art. 175 of the CEC. Thanks to the rights of associations, organizations and institutions envisaged therein, they feasibly support probation officers' work. Operating associations, organizations and institutions are mainly specialized and prepared to work with the convicts who require additional therapy programmes or treatment. Entrusting those subjects with some important duties of professional probation officers, including full responsibility for probation or filing motions with a court, should entail the use of their huge potential and, at the same time, relieve professional probation officers, who are excessively burdened with tasks and obligations ${ }^{32}$.

Preparing inmates to life after prison, participation of social organizations within this scope may also be manifested in the cooperation with professional probations officers who, among others, are obliged to co-organize support and assistance provided to convicts through cooperation with inmates and prison service as well as bodies of government and local government administration, associations, foundations, organ-

30 Rada Główna do Spraw Readaptacji i Pomocy Skazanym, Uczestnictwo społeczeństwa w wykonywaniu orzeczeń sądu, Warszawa, 7 November, 2013.

31 Journal of Laws of 2016, item 969.

32 K. Postulski, Kodeks karny wykonawczy. Komentarz, Lex 2016. 
izations, institutions and other entities whose activities are aimed at helping inmates to socially re-adapt ${ }^{33}$.

Nevertheless, it should be emphasized that parole is not probation in a strict sense because it is not a measure of response to a crime. However, this institution belongs to the measures of probation, which is decided by a conditional nature of a release and a trial period as well as probation the released person is put on whose legal effects are conditioned on the course and results of the trial ${ }^{34}$. As far as the participation of social factor in the enforcement of such a decision is concerned, it is analogical to other institutions of probation which are connected with the obligation of putting a convict on probation.

\section{Electronic monitoring programme}

Electronic monitoring is a relatively new form of supervising inmates, which emerged in result of technological development, including technologies allowing remote monitoring of a place of whereabouts of a person carrying a transmitter. It was introduced to the Polish legal system by the Act of an episodic nature ${ }^{35}$. As of 1 July 2015 this institution was adopted (together with relevant changes) to the Criminal Executive Code (Chapter VIIa). Before 30 June 2015 electronic monitoring programme was in force as one of the systems of deprivation of liberty enforcement. Whereas since 1 July 2015 the following penalties may be adjudicated and enforced together with electronic monitoring: restriction of liberty in a form of the obligation to stay in a place of permanent residence or another designated place with accompanying daily supervision (probation) (Art. $34 \$ 1$ a point 2 of the Criminal Code), a ban to approach specified individuals (Art. 41a $\$ 1$ and 2 of the Criminal Code), the obligation to stay in a place of permanent residence or another designated place during some mass events covered by the ban (Art. $41 \mathrm{~b} \$ 3$ of the Criminal Code), and security (protective) measure (Art. 93a $\$ 1$ point 1 of the Criminal Code). However, experiences ensuing from the operation of electronic monitoring programme after 1 July 2015 as a form of restriction of liberty enforcement indicate a diametrical decline in a number of persons covered by this system even though development of electronic monitoring, with regard to both the system's capacity and organizational and technical level, allows a wider use of this system in criminal law, especially through its subsequent use during the enforcement of deprivation of liberty ${ }^{36}$. That is why Art. $34 \$$

33 Rada Główna do Spraw Readaptacji i Pomocy Skazanym, Uczestnictwo społeczeństwa w wykonywaniu orzeczeń sądu, Warszawa, 7 November 2013.

34 A. Marek, Kodeks karny. Komentarz do art. 77, Lex 2010, teza 1, p. 139.

35 Act of 7 September 2007 on the Enforcement of Deprivation of Liberty Outside Prison in the System of Electronic Monitoring (uniform text: Journal of Laws of 2010 No. 142, item 960, as amended).

36 K. Postulski, Komentarz do niektórych przepisów ustawy z dnia 6 czerwca 1997 r. Kodeks karny wykonawczy, w zakresie zmian wprowadzonych ustawą z dnia 11 marca 2016 r. o zmianie ustawy - Kodeks karny oraz ustawy - Kodeks karny wykonawczy, Lex 2016. 
1a point 2 of the Criminal Code and Art. $35 \$ 3$ of the Criminal Code on sentencing to restriction of liberty involving the obligation to stay in a place of permanent residence or another designated place with accompanying electronic monitoring as well as Criminal Executive Code's provisions on the enforcement of restriction of liberty in this form have been repealed as of 15 April 2016.

Activities connected with the organization and control of the enforcement of penalties with the use of electronic monitoring and obligations imposed in connection with them have been assigned to probation officers (Art. $43 \mathrm{~d} \$ 3$ of the Criminal Executive Code). Although the amendments did not directly envisage the participation of a social probation officer in exercising control over the enforcement of penalties within this system, the same as previously, a professional probation officer may cooperate with entities mentioned in Art. 38 of the Criminal Executive Code (see comments to point I).

With regard to electronic monitoring, professional probation officers tasks' are different from ordinary probation; contacts with inmates are not of a controlling nature because electronic monitoring system and authorized probation entity "watch" over the regularity of penalty enforcement. Probation officer's activities are mainly aimed at providing inmates with support necessary in everyday personal or professional matters, which facilitates building a trust-based rapport ${ }^{37}$. However, the position of a probation officer in the process of social rehabilitation of inmates subject to electronic monitoring is not marginal because the existence of modern technology merely enhances the system which cannot replace a social factor.

Referring to the so called probation institutions and their possible legal regulations, it is worth mentioning the model functioning in England and Wales, which has been subject to privatization ${ }^{38}$. In 2013 , serious changes to the model of probation institutions were proposed through the so called Transforming Rehabilitation ${ }^{39}$ - the government program of offenders management of 1 February 2015, whose goal is to counteract convicts' return to crime. The reform is heading towards a neoliberal perception of managing probation through privatization and outsourcing some tasks of a welfare state and, at the same time, concurrent strengthening of certain spheres of the State coercion, in particular a sphere of employment and security ${ }^{40}$. Implemented changes are based on the engagement of a public sector in probation, i.e. National Public Probation Service, which would be responsible for app. 12\% of the so called high risk inmates, and a private sector - the so called Community Rehabilitation Companies, which would be responsible for rehabilitation of low and medium risk

37 A. Kiełtyka, A. Ważny, Ustawa o wykonywaniu kary pozbawienia wolności poza zakładem karnym w systemie dozoru elektronicznego. Komentarz, Warszawa 2011, p. 218-220.

38 W. Fitzgibbon, J. Lea, Defending probation: Beyond privatisation and security, "European Journal of Probation" 2014, Vol. 6(1) p. 27-28, ejp.sagepub.com (08.11.2016).

39 https://consult.justice.gov.uk/digital-communications/transforming-rehabilitation/results/transforming-rehabilitation-response.pdf, (14.11.2016).

40 W. Fitzgibbon, J. Lea, Defending..., op. cit., p. 29. 
inmates, and additionally exercise control over inmates sentenced to 12 months of deprivation of liberty after their release from prison (relevant legal regulations have been included in the Offender Rehabilitation Act of $2014^{41}$. CRCs' administration and management have been entrusted to social organizations and private entities ${ }^{42}$.

The first audit carried out in 2016 in this sector revealed positive aspects of the above changes and drew attention to ensuing threats too. National Audit Office ${ }^{43}$ stressed that the reform of a probation model was introduced at a right time whereas its measurable financial effects are already discernible. On the other hand, however, such a manner of managing convicted offenders and payment by result (private entities are paid for result) may, first of all, entail that these enterprises will focus solely on profit forgetting about the convicted offenders' needs and, secondly, lead to a certain manipulation of data reflecting actual activities of the enterprises - NAO confirmed that some controlled enterprises failed to submit appropriate information about their operation $^{44}$. Subsequent audits also revealed new irregularities and negligence in CRC's operation ${ }^{45}$. The reports on the functioning of these institutions in London confirm that many offenders have not been seen for weeks or months and some "have been lost in the system altogether" 46 .

\section{Conclusion}

Associations, foundations, organizations and institutions whose aim is to implement tasks specified in Chapter VII of the Criminal Executive Code as well as churches and other religious groups and trustworthy persons may cooperate in the enforcement of penal responsive measures connected with deprivation of liberty in particular. This distinction emphasizes that just this segment of executive proceedings is most susceptible to social rehabilitation, social, cultural, educational, sport and religious activity pursued by external entities ${ }^{47}$. Amended Art. 175 of the Criminal Executive Code has considerably extended the rights and obligations of associ-

41 http://www.legislation.gov.uk/ukpga/2014/11/notes (14.11.2016).

42 W. Fitzgibbon, J. Lea, Defending..., op. cit., p. 26. Zob. także M. Muskała, Służba kuratorska w Anglii i Walii, „Probacja" 2015, No. I, p. 51-66.

43 Pełen raport o funkcjonowaniu zreformowanego modelu probacyjnego dostępny na stronie: https://www.nao.org. uk/report/transforming-rehabilitation.

44 R. Cooke, Is the Privatised Probation Service Working?, http://www.seven-resourcing.com/criminal-justice/news/ privatised-probation-service-working/ (14.11.2016), and S. Fenton, Watchdog criticises Government's privatisation of probation services, http://www.independent.co.uk/news/uk/politics/national-audit-office-watchdog-savages-governments-disastrous-privatisation-of-probation-services-a7010496.html (14.11.2016), A. Travis, Liz Truss calls for rapid completion of probation privatisation review, "The Guardian", 06.12.2016, https://www.theguardian. com/society/2016/dec/06/liz-truss-calls-rapid-completion-probation-privatisation-review (29.12.2016).

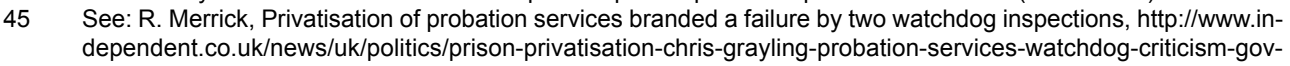
ernment-failure-a7344361.html (14.11.2016).

46 A. Travis, Privatisation of probation service has left public at greater risk - report, „The Guardian”, 15 December 2016, https://www.theguardian.com/society/2016/dec/15/probation-privatisation-public-greater-risk-report-glenys-stacey (29.12.2016).

47 K. Postulski, Kodeks karny wykonawczy..., op. cit. 
ations, organizations and institutions whose aim is to participate in the enforcement of penalties, penal measures and protective and preventive measures connected with deprivation of liberty; almost up to the level of professional probation officers with regard to the scope of their tasks embracing the enforcement of probation. Cooperation between bodies enforcing a sentence occurs during the enforcement of restriction of liberty, provision of support and assistance in social re-adaptation of inmates released from prison, or the enforcement of probation measures. Due to their profiles or qualifications, operating associations, organizations and institutions are an excellent supplement of court probation. Entrusting them with probation activities or services not only relieves professional probation officers but is also a form of "social supervision or control" over the enforcement of adjudicated penalties and measures.

Nonetheless, these entities still attract insignificant interest of State institutions to establish mutual cooperation, opposite to the French example described above. According to the above mentioned results of surveys and questionnaires, a small percentage of convicted offenders serves a sentence within social structures. Whereas examples of penitentiary systems of European counties provide us with many ideas which could be used to improve our penitentiary model. The French model seems to be the most effective because it arises interest of most citizens who wish to take part in social life. The British example indicates that privatization of the sector of offenders management creates considerable threats, mostly because of a risk of losing a goal of action due to a pursuit of profit by all means. However, entrusting social organizations with the enforcement of probation of a specific kind of offenders (those least demoralized) appears to be an interesting solution. The more so since cooperation between associations or organizations and convicted offenders is a visible expression of compensating society for the committed wrongful acts within the framework of general prevention. The above mentioned idea of K.A. Politowicz appears to be equally interesting: he believes that community service should be tailored to match personal attributes of an offender who, using his or her qualifications, could help others at his or her best. Unpaid and controlled work for social purposes contains all elements of punishment thus fulfilling its retributive aim and preventive objectives involving, among others, integration of a perpetrator with society and society with a perpetrator. Recent amendments of the Criminal Code should encourage courts to sentence offenders to this type of restriction of liberty more often as this punishment is fair from a social point of view. At the same time, examples of European solutions within the scope of engaging society in the enforcement of punishment should be a guideline for the Polish legislator. 


\section{BIBLIOGRAPHY}

Cooke R., Is the Privatised Probation Service Working?, http://www.seven-resourcing.com/ criminal-justice/news/privatised-probation-service-working/.

Fenton S., Watchdog criticises Government's privatisation of probation services, http://www.independent.co.uk/news/uk/politics/national-audit-office-watchdog-savages-governments-disastrous-

-privatisation-of-probation-services-a7010496.html.

Fitzgibbon W., Lea J., Defending probation: Beyond privatisation and security, "European Journal of Probation" 2014, vol. 6(1), ejp.sagepub.com.

Giętkowski R., (in:) R.A. Stefański (ed.), Kodeks karny, Warszawa 2015.

Herzog-Evans M., French third sector participation in probation and reentry: Complementary or competitive?, "European Journal of Probation" 2014, vol. 6(1), ejp.sagepub.com.

Janus-Dębska A., Praca na rzecz społeczności lokalnej w wybranych krajach europejskich, "Probacja” 2013, No. IV.

Janus-Dębska A., Uwarunkowania efektywnego wykonywania kary ograniczenia wolności, "Probacja" 2014, No. III.

Janus-Dębska A., Współpraca kuratorów sądowych z osobami organizującymi i nadzorującymi prace skazanych w ramach kary ograniczenia wolności w świetle badań własnych, "Probacja” 2015, No. III.

Kiełtyka A., Ważny A., Ustawa o wykonywaniu kary pozbawienia wolności poza zakładem karnym w systemie dozoru elektronicznego. Komentarz, Warszawa 2011.

Ludlow A., Transforming Rehabilitation: What lessons might be learned from prison privatisation?, "European Journal of Probation" 2014, vol. 6(1), ejp.sagepub.com.

Merrick R., Privatisation of probation services branded a failure by two watchdog inspections, http:// www.independent.co.uk/news/uk/politics/prison-privatisation-chris-grayling-probation-services-watchdog-criticism-government-failure-a7344361.html.

Nowak B., Reintegracja społeczna skazanych w wybranych państwach Unii Europejskiej, „Resocjalizacja Polska" 2015, No. 10.

Ornowska A., "Pot zamiast odsiadki”: Dylematy związane z wprowadzeniem do niemieckiego porządku prawnego elementów kary pracy społecznie użytecznej i próby ich przezwyciężenia (część I), "Probacja" 2014, No. I.

Ornowska A., „Pot zamiast odsiadki”: Dylematy związane z wprowadzeniem do niemieckiego porządku prawnego elementów kary pracy społecznie użytecznej i próby ich przezwyciężenia (część II), "Probacja” 2014, No. II.

Politowicz K. A., O potrzebie i sposobach rozszerzania bazy dla wykonywania pracy społecznie użytecznej po nowelizacji kodeksu karnego, "Probacja” 2015, No. III.

Postulski K., Kodeks karny wykonawczy. Komentarz, Lex 2016,

Postulski K., Komentarz do niektórych przepisów ustawy z dnia 6 czerwca 1997 r. Kodeks karny wykonawczy, w zakresie zmian wprowadzonych ustawą z dnia 11 marca 2016 r. o zmianie ustawy - Kodeks karny oraz ustawy - Kodeks karny wykonawczy, Lex 2016. 
Postulski K., Zmiany w wykonywaniu kary ograniczenia wolności, "Probacja” 2011, No. III. Szymanowski T., (in:) T. Szymanowski, Z. Świda, Kodeks karny wykonawczy. Komentarz, Warszawa 1998.

Travis A., Liz Truss calls for rapid completion of probation privatisation review, "The Gu- ardian”, 06 December 2016, https://www.theguardian.com/society/2016/dec/06/ liz-truss-calls-rapid-completion-probation-privatisation-review.

Travis A., Privatisation of probation service has left public at greater risk - report, "The Guardian", 15 December 2016, https://www.theguardian.com/society/2016/dec/15/ probation-privatisation-public-greater-risk-report-glenys-stacey. 